\title{
Policy Overcomes Confessional Hurdles: A Policy Strategy Tackles Challenges in the Segmented Society and State of Lebanon
}

\author{
By Joseph P. Helou*
}

\begin{abstract}
I flesh out an analysis of how Lebanese Zu'ama or political elite manipulate various aspects of politics in Lebanon to maintain a firm grip of the confessional communities they represent. The political order resulting from the Za'im's intervention in political life impedes policy formation on a non-confessional basis and precludes the development of state-society relations without the powerful intermediary role of the Lebanese Za'im. Therefore, I suggest a policy strategy that centers on a gradual and partial reform to break away from the powerful influence of the Lebanese Zu'ama in political life and towards a more participatory role for Lebanese citizens in the political order in Lebanon.
\end{abstract}

Keywords: confessionalism, political spaces, policy strategy, za'im

\section{Introduction}

I aim to discuss how Lebanese political leaders stunt the formation of policies through the manipulation of the political system, and suggest adequate policies to overcome this hurdle. I seek to explain how the political leaders commonly known as Za'im or plural Zu'ama - harnessed a network of patronclient social services and manipulated the confessional sentiments of their supporters to influence the course of politics in Lebanon. In this respect, I highlight how Lebanese Zu'ama exploited their relations with foreign powers, profited from prevailing ideologies, and consolidated their influence through power sharing arrangements that more often served their interests as opposed to the broader constituencies they purportedly represented. To break away from the detrimental influence of Zu'ama on Lebanese politics, I aim to flesh out a policy strategy that, if applied, can help Lebanese society rotate away from their heavy dependence on Lebanese Zu'ama for social services, basic rights, and the attainment of their livelihoods. I aim to outline- or at least spark a debate regarding- the contours of the policy strategy that seeks to debilitate the influence of the Lebanese Zu'ama on politics; should it set comprehensive or incremental policy goals with the aim of reforming state-institutions or society?

I argue that the ability of the Lebanese Zu'ama to reap political benefits from the Ottoman, French, and Syrian intervention in Lebanese politics consolidated their position in the political system and strengthened their grip on society by virtue of their role in aggravating confessional tendencies. They were able to reinforce their presence in the Lebanese political order by forging

${ }^{*} \mathrm{PhD}$ Candidate, University of Exeter, UK. 
patron-client relations based on the dispersion of social goods, engineering power sharing arrangements to carve up a sphere of influence for themselves in Lebanese politics, and mobilizing the people by embracing popular ideological inclinations, all of which tipped Lebanon's sensitive political balance by virtue of deepening inter-confessional cleavages. With the passing of time, this confessional order became more deeply entrenched and immune to change, weighing negatively on the process of policy formation. But I argue that Lebanon can eschew policy failures by adopting a more realistic policy approach that aims to resolve issues incrementally and to reform society, instead of restricting policy focus to state-centric and comprehensive proposals. Whether discussing policy reforms relating to personal status issues, electoral laws for parliamentary elections, or a basket of other civil rights, the policy process should shun away from a strict focus on amending the existing confessional order and concentrate more heavily on creating political spaces or opportunities whereby Lebanese individuals, who are also members of a confessional community, can associate with one another and with the state on a non-confessional basis.

The forthcoming parts expatiate on the challenges the Zu'ama pose to policy formation in Lebanon and flesh out a policy strategy that seeks to deal with this predicament. In the first part, I attempt to define the meaning of confessionalism and the way it is fleshed out herein. I show how the Zu'ama played a role in power sharing arrangements, national consensus and conflict, patron-client relations, and relations with foreign powers, and through their intervention in these fields helped fortify the confessional political order. More importantly, I explain what dimensions of the confessional political order, which the Zu'ama helped bring about, rendered it un-amenable and obstructive to the process of policy formation. In the second part, I elaborate a policy strategy, which serves as a model for policy formation in segmented societies, that specifies how expansive or narrow the policy goals, objectives, and targets ought to be in the case of a divided society such as the one in Lebanon. This policy strategy divulges the importance of reforming society gradually; it also reveals how the creation of political spaces in which individuals can participate on a non-confessional basis weakens confessional bonds, which could then form the basis for a post-confessional order. The analysis does not focus on a single case study in part two, but illustrates with several examples to showcase the strength of the proposed approach.

\section{Part One: Confessionalism as a Political Order}

The volatility of the term confessionalism conjures multiple meanings often misguiding ones- and thus requires elucidation. Beydoun (2003) denotes some of these multiple interpretations of confessionalism stating that "Confessionalism... has a range of meanings that gives it a certain vagueness and allows for all sorts of ambiguities. It may refer to the politicoadministrative system of government, the social reality of multicommunalism, the institutional 
organization - in the widest sense - of a community, a collective or individual attitude tending to involve communal institutions in the global organization and the management of society, the rather exclusive, or at least privileged, identification with a religious community, affiliation with an institution or even a way of communal thinking, acting or living, etc (Beydoun 2003)."However, he adopts the term "in the subjective and objective sense of collective identification and its institutional expression in global society (Beydoun 2003)". Arguably, when placed in the context of Lebanon, confessionalism is actualized through citizen's identification with their sect, which also circumscribes the relationship of citizens to the state based on the sect's apportioned representation in the political order. Even if individuals decide to dissociate from their confessional affinities and identify themselves as non-sectarian, secular, or atheist, they are bound to the legal jurisdiction of their sect - to the laws, procedures, and decisions of one of the 17 religious courts in Lebanon- in personal status matters such as marriage, divorce, and inheritance.

Confessionalism entraps society in a vicious self-reproducing circle that impedes policy formation outside the domain of the confessional order. This watertight order manages to encompass every aspect of the Lebanese society. Even non-governmental Organizations, which spearhead change by calling out policy shortcomings, reproduce sectarianism in Lebanon. Kingston (2013) illustrates this point through his examination of the factors that reproduce sectarianism in the politics of disability, environment, and women's rights associations in Lebanon, and finds fault in the prevailing institutional order and human agency. In other words, though the Lebanese people are conscious of the deleterious effects of the confessional order, the Lebanese society and state dovetail to reinforce people's collective identification on a confessional basis, and express that confessional identification in the institutional setting of the state. The more egregious impact of confessionalism lies in the annual costs it imposes on the Lebanese society. Chaaban (2011) contends confessional segregation -voluntary preference to associate with individuals from one's confessional group - in the fields of education, housing, and personal status issues inter alia, inflicts an annual cost of three billion U.S. Dollars on society. Therefore, before delving into an examination of the most convenient policy making approach to tackle the calamities resulting from this confessional order, an analysis regarding the factors that had established and maintained this confessional order in Lebanon over time is appropriate.

\section{Zu'ama-client Relations Boost Confessional Mobilization}

I contend that the Lebanese Zu'ama played an essential role-if not the main role-in intensifying the confessional mobilization of society by nurturing a clientelist network of social services and subsequently exploiting it for political purposes. The za'im dispensed favors in return for his client's unwavering political loyalty and support. He remained in close contact with his supporters through a network of middle men or Qabadays. These middle men convened meetings, established contacts, and often guaranteed the votes of 
individuals and families during elections (Khalaf 1968). They also brokered the transmission of orders, goods, and services between the Za'im and his political clients (Khalaf and Denoeux 1988). In the 1958 civil conflict, for example, Ibrahim Qulaylat, a 16 year old qabaday, participated in the civil fighting (Johnson 1986), and mobilized fighters for the Lebanese politicians supporting the pro-Arab camp-predominantly Muslim following-to combat the supporters of the Lebanese politicians who were backing the pro-Western camp - predominantly Christian following. This highlights how patron-client relations can culminate in the polarization and mobilization of public opinion-more often along confessional lines-and strengthen political identification with the elite as opposed to the state, further fracturing an already fragile order.

I strongly argue that the ability of the Lebanese Zu'ama to deliver an impact on Lebanese politics - whether they are inside or outside the government or the political system-is, in part, due to the nature of their emergence and persistence in Lebanese politics. Khalaf discusses the emergence and the role of three types of Zu'ama: the feudal, administrative, and urban za'im (Khalaf 1968). The system of feudal za'ims had enjoyed political patronage by virtue of their ownership of land on which the people worked and simultaneously pledged loyalty to the Feudal Za'im. The demise of this feudal system in 1860 culminated in the emergence of the administrative Za'ims that usually served as magistrates or bureaucrats under the Ottoman rule. A number of Lebanon's more influential political personalities are the descendents of the administrative Za'ims. The urban za'im is a city notable who gains patronage by politically capitalizing on his wealth to build a clientele. The urban Za'im is probably the most reoccurring phenomenon within Lebanese politics, since a number of Lebanon's current political elite have amassed fortunes in Africa and the oil-rich monarchies of the Arab Gulf and have capitalized on that wealth to gain political clout. Since the only criteria for leadership within this class of Za'ims is material wealth, a number of individuals have obtained their ticket into the Lebanese political order by using their wealth to foster networks of social services and employ them to manipulate society - chiefly the confessional community to which they belong. Their actions continue to inflict negative repercussions on the Lebanese political order by strengthening society's affiliation with the Za'im, often at the expense of the state, let alone debunking state institutions and policy formations within those institutions.

In no way do I attempt to proclaim the exceptionalism of Lebanon's political elite or its patron-client structures. Mexico, for instance, is also a revealing example of how the elite practices a hegemonic relationship with their clientele (Pansters 2012). But I try to show that the Zu'ama patronage system of the Lebanese society ironically carries the seeds of both the stability and conflict in Lebanon, and precludes the formation of a unifying civic relationship between the people and the state (Khalaf 2004). Therefore, only by understanding the extent to which the Zu'ama dominated political life in 
Lebanon could the proposal of adequate policy strategies to resolve political predicaments be advanced.

By tying individuals in an intricate web of social services, the Lebanese Za'im manages to build a loyal base of support in two important ways. First, the za'im makes himself available for his clients and continuously provides governmental services (Johnson 1986). Second, he forges contacts within the business community to grant his clients employment, contracts and capital (Johnson 1986). Depending on the client's demands and political significance, the za'im may be willing to dispense public works contracts, governmental concessions, employment in the state and private sectors, promotion within the professions and civil service, free or cheap education and medical treatment in government or charitable institutions, and even protection from the law. In return, the za'im receives his client's votes in elections, full support during political challenges, greetings during feast days, and backing on all other political issues. Arguably, the Za'im has an interest in the perpetuation of the patron-client network of societal dependence on the elite for social services, and thus barely pays lip service to advocating policy and reforming the state from within. These politicians prefer dealing with their counterparts from other confessions through what Hottinger calls "a backstage of personal, confessional, regional group, family and interest group politics" (Hottinger 1961), and maintain a keen interest in preserving influence over the confessional group to which they belong in order to fortify their position within the Lebanese political order.

Because of this relationship that tied the Lebanese Za'im with his clientele, some Zu'ama that drop out of a formal political role - council of ministers and parliament etc - in Lebanon continue to possess the resources to mobilize supporters. Through this system, the Za'im can influence politics by rallying the people, swaying supporters, and fanning the flames of conflict by driving those supporters to the streets. Considering that the Za'im often bequeaths his political position or authority to a son or family member, this Za'im client relationship not only witnesses inter-generational replication, but also delivers a powerful impact on the political system in Lebanon by locking the people within a vicious and regenerating circle of societal domination. The Zu'ama do not simply rely on their clients as voters in the political process of elections, but also foster a clientele who are ready to pledge allegiance to them and carry arms in defense of the Za'im's political interests if needed. Thus this political configuration does not fully resemble the system of corporations and individuals that finance the campaign of the presidential hopefuls in the U.S.A or France in return for some political favor if the sponsored candidate assumes office, because competition is not confined within institutional boundaries but could devolve into violent clashes. Seeing that their relationship with the Za'im generates a tremendous amount of political and economic benefits, the Za'im's clientele heed the calls of their political patron and thus sustain this system of community domination (Cammett 2014). 


\section{Zu'ama Consolidation of Power through the Confessional Order}

I argue that the Lebanese Zu'ama benefited from the introduction of political representation on the basis of confessional quotas to strengthen their authority within the confessional communities they belonged to. They played an instrumental role in the confessional institutions and practices advanced by the Ottoman Empire, French mandate, and Syrian suzerainty of Lebanon. They operated within the confines of the confessional power sharing arrangements fashioned or buttressed by these foreign powers that brought about some semblance of stability and molded a confessional order that still backlashes on - if not totally precludes - the formation of policies on a non-confessional and civil basis.

The Lebanese Zu'ama exploited the set of institutions and practices advanced by foreign powers to strengthen the confessional order, which encouraged people to collectivize in confessional groups. They seized the opportunity to represent their communities on the first multi-confessional government administration in Mount Lebanon, which came into existence upon the signing of the European-sponsored Reglement organique of 1861 that brought the internecine conflict in Mount Lebanon between the Christian Maronite community and the Muslim-Druze community to an end. As a consequence of this agreement, the Mutasarrifiya (Ottoman administrative body) emerged with an administrative council that was comprised of twelve elected members from various confessional communities (Traboulsi 2012); six were Christians (two Maronite, two Greek Orthodox, and two Greek Catholic) and six were Muslim (two Sunni, two Shiia, and two Druze). A subsequent revision of the Reglement organique in 1864 gave Christians a seven to five edge over their Muslim counterparts.

Although the establishment of an administrative council with seats allocated for the representatives of confessional communities helped forestall conflict - especially as a power sharing agreement that emerged following a bloody civil war between various confessional communities in Mount Lebanon, it ironically dispersed the seeds for future conflicts by transforming the role of the political Za'im from representing the inhabitants of a geographical district, regardless of confessional affinity, to predominantly representing the confessional community to which they belonged. Accordingly, members of every confessional community identified and built solid relations with those Zu'ama that represented their confessional community on the council. This association with some of the political elite on confessional grounds paved the way for weak state-society relations, since every confessional community identified with their representatives and not the council as a whole, and provided the Zu'ama the liberty to shoulder the blame of political failures on their counterparts and escape accountability. In addition, the confessional allocation of political positions in the Lebanese political order invariably concentrated the political debate on issues of power sharing and limited the avenues for political competition, as vindicated by the course of politics in Lebanon. As a result, inter-Za'im competition became focused on the 
exploitation of the state to gain a larger share within the political order and consequently more economic returns to dispense services to their support-base.

While the Zu'ama and the political elite (chiefly Christians) who favored the new polity of a Greater Lebanon, which appended many Muslim territories to the polity of Mount Lebanon under the French mandate, received the backing of France, those irredentist Zu'ama or political elite (who were mainly Muslims seeking union with Syria or the broader Arab world) were disfavored by French authorities, an issue that contributed to the aggravation of confessional politics in Lebanon. In 1932, for example, the French mandate authorities refused the candidacy of Sheikh Muhammad Al-Jisr, a SunniMuslim leader from Tripoli, to the presidency, and suspended the constitution and disbanded parliament to prevent the election of a Muslim president (Traboulsi 2012). They advanced numerous safeguards to protect the fledgling polity of Lebanon, whose adherents were overwhelmingly Christian, against the irredentist claims of Muslim communities, who favored a union with Syria or the larger Arab World (Solh 1988). These safeguards included the right of the high commissioner to rule by decree to limit the prerogatives of the council; French objection to any legislation that might lead to the dismemberment of Lebanon; and French pressure exerted on extreme Syrian unionists or Arab nationalists to withdraw from elections inter alia. As a result, Muhammad Jamil Beyhum, an Arab nationalist, succumbed to pressure and withdrew from parliamentary elections in 1922 (Solh 1988).

These formative years witnessed the consolidation of the authority of Zu'ama within the confessional order through a set of institutions and practices, which invited the Lebanese society to associate with the state - and especially their preferred Za'im - on a sectarian basis, rendering the prevailing political order more resistant to non-confessional arrangements. This political order, which allocated the presidency of the republic to a Maronite, speaker of the house to a Shiia, and premiership to a Sunni, and accorded every confessional group a specific number of parliamentary seats (based on a six-to-five Christian-Muslim ratio becoming six-to-six after the 1975-1990 Lebanese civil war), rendered inter-Zu'ama exchanges - both those occurring during conflict and peacetime - as tantamount in effect to overt declarations of enmity or amity between the confessional groups that these Zu'ama represented (AbulHusn 1998). The negotiations of political settlements, pacts, and power sharing agreements between Lebanon's Zu'ama always took on a confessional die. Khalidi, for example, regards all power arrangements in Lebanon to include a link between the issue of identity and both sectarian structures and intersectarian power balances (Khalidi 1989). He argues that a shift in emphasis from one aspect of the political formula to another reflects the underlying changes in the regional power balances and the change in the identity of the external power sponsoring the power arrangement. In addition to playing a role in mediating or intensifying conflict, external intervention in Lebanese affairs deepened the ideological divide between different confessional groups, as assistance provisioned to a confessional group adopting an exclusive ideology, such as Christians with Lebanism and Muslims with Arabism in the Lebanese 
civil wars of 1958 and 1975 (Salibi 1976), rendered irreconcilable views as recipes for inter-communal conflict.

Syrian suzerainty of Lebanon through its co-sponsorship of the Ta'if accords, the Saudi-brokered treaty to resolve the Lebanese civil war, and through devising the Brotherhood Agreement, which placed Lebanon within Syria's immediate political and security orbit, reshuffled the political landscape and further consolidated confessionalism as the de jure political order. The Ta'if accords, for instance, introduced amendments to the Lebanese constitution that enshrined the confessional affinity of the President of the republic, Premier, and the speaker of the house in the constitution (Dabbagh et al. 1997). It also spelled a confessional parity between Christians and Muslims in parliamentary representation, allocating each group sixty-four members of parliament, let alone vindicating confessional parity across all government bureaucracies. The Brotherhood agreement permitted Syria an upper hand in determining and meddling in the political and security affairs of Lebanon (Brotherhood Agreement 1991) - and at times extended beyond those realms into the intricacies of the Lebanese political system, allowing it to tip one confessional group against another and capitalize on societal divisions. Moreover, Syria's intervention in Lebanon impacted Lebanese politics by rendering the Lebanese political elite more subservient to the interests of Damascus in Lebanon, an issue which weighed in heavily on post-war elite politics (El-Husseini 2012). Arguably, this accumulated set of political institutions and practices withstood the test of time and became immune to the reformist efforts of progressive individuals and politicians, who introduced policies on a non-confessional basis. The way out of this current predicament lies in the adoption of a proper policy strategy that allows for the association of society with the Lebanese state on a non-confessional basis. Evidently, this attempt will collide with the interests of the Lebanese Zu'ama whose manipulation of the confessional order had provided them a free hand in mobilizing their communities.

I argue that every power-sharing agreement, ideological view, foreign state sponsorship of a cause or political inclination inside Lebanon, and clientelist network of political favors and social goods presented a golden opportunity for the Lebanese Zu'ama to strengthen their grip over the confessional community in which they belonged - evidenced through their successful mobilization of their confessional communities in the 1958 and 1975 Lebanese civil wars inter alia. Therefore, the octopus-like political tentacles of the Lebanese Zu'amafar reaching in scope-help preserve Lebanon's watertight confessional order by virtue of fostering the aforementioned Za'im patronage system, which confined society to strict sectarian parameters in personal status matters, economic affairs, the attainment of many basic rights such as medical care, and numerous political favors, let alone sustaining the Za'im's dominant role in Lebanese politics. This confessionally-imbued political order structurally disposed the Lebanese society to associating more closely with the Za'im as opposed to the state, and locked society up in a political order in which they invariably exhibited the proclivity to express narrow parochial interests instead 
of working towards an all-encompassing cross-confessional civic and national outlook. By adopting a policy strategy that centers on partial reform and invites Lebanese society to directly engage with the Lebanese state, I contend this opens up a hole in the wall of Lebanon's confessional system while strengthening the direct bonds between society and the state without the Zu'ama assuming the role of the intermediaries.

\section{Part Two: A Policy Strategy for the Confessional Society and State of Lebanon}

Whether policy makers aim to debilitate the political prerogatives of the Lebanese Zu'ama, tone down confessionalism's institutional expression inside the framework of the state, or put forth sweeping reforms to introduce secularism as a political order, they ought to be introduced in a piece meal and injected gradually into the Lebanese political order. Arguably, if a single policy places the objective of abrogating confessionalism, it is doomed to fail because of the multifaceted character of the confessional order that manages to regenerate itself on the societal level, even if the legal prerogatives of the confessional groups are dissolved within the political system. This is why any proposed policy should aim to liberate political spaces to insure the citizens' participation in the political system on a non-confessional basis and without the intercession of the Lebanese Zu'ama. In order to loosen Zu'ama's grip of the Lebanese society, adequate policy strategies need to increase the level of participation of Lebanese society in political life by creating political spaces in which Lebanese individuals can carry out their obligations and receive their rights without the intercession of a powerful Za'im. In a number of volumes on policy proposals for Lebanon, several towering academic figures expatiated on policies to redress shortcomings regarding Lebanon's public administration, business laws, foreign affairs, education, and identity, among many, but rarely expounded on effective and full-fledged policy strategies to bridge those gaps (Choueiri 2007, Hanf and Salam 2003, Salam 2004). Therefore, this part argues that for policy to be efficacious, it ought to adopt the components of the aforementioned policy strategy, and illustrate with examples herein to vindicate this point.

\section{Reforming the Electoral Law}

A number of draft proposals on electoral laws for parliamentary elections were discussed among the political elite of Lebanon, and some were scuttled in parliament, because they threatened the political standing of current parliamentary blocks. While Lebanese Zu'ama deemed the current majoritarian electoral law unjust, they have reached a deadlock in attempting to settle for an alternative. The proposed Orthodox electoral law (Orthodox Electoral Law 2013), which embraced proportional representation as its guiding principle, was turned down in parliament not merely because it restricted Lebanese voters to a choice of candidates from their own confessional community, but because 
it threatened to downsize the parliamentary blocks of certain political parties who have benefited from the majoritarian electoral system. Under the current majoritarian electoral system - with multi-candidate and closed electoral slates, those Zu'ama whose supporting confessional community predominate an electoral constituency usually play a decisive role in determining the representatives of other confessional communities or political persuasions through "the winner takes all" majoritarian system. The majoritarian electoral system poses manifold challenges in Lebanon due to the confessional cleavages afflicting its political order. Majoritarian elections threaten to isolate important segments of the Lebanese society by under-representing them in parliament. As a consequence, political bickering over the size of electoral constituencies, the principle of proportional or majoritarian representation, and the political interests of Lebanese Zu'ama in the electoral system may become a recipe for conflict.

The only way to break the existing deadlock is to adopt a strategy that centers on partial reform as opposed to introducing radical and sweeping solutions. Ideally, if the Lebanese people are able to implement their calls for a proportional electoral system-whether through lobbying, pressure groups, and/or social movements, the Lebanese society would have attained the fairest form of representation for all confessional, secular, and diverse ideational persuasions alike. But seeing that the Lebanese Zu'ama are adept at regenerating the confessional order to maintain their political prerogatives across time, the policy strategy reformists ought to adopt is one that incrementally injects proportional representation as a principle into Lebanon's parliamentary elections. Since the majoritarian system preserves the privileges of confessional leaders and the proportional system jeopardizes those very same privileges, the most convenient way out of this predicament is to create some political space in which individuals can compete in the electoral race on a civil basis. Arsenian Ekmekji argues in favor of adopting the Boutros commission draft - dubbed after the commission tasked with proposing a new electoral law for Lebanon-that proposes mixed-electoral constituencies according to proportional and majoritarian representation (Arsenian Ekmekji 2012). She contends that the implementation of the Boutros Commission Law can take place gradually (over a period of three electoral cycles/twelve years) and culminate in the creation of a bicameral Parliament with a senate, which in turn insures confessional and civil-secular privileges. In other words, though a proportional electoral law would be the ideal scenario to insure a better representation of the Lebanese society, the more conducive proposal for implementation is the mixed-proportional and majoritarian system precisely because it introduces reform gradually, creates political space for unconventional or new political contenders to hop into the political system, influences society to participate more actively in parliamentary elections, and renders political concessions or agreement on such a law less threatening to the immediate interests of the existing Zu'ama. 


\section{Social Reforms}

Through the confessional system, the Lebanese Zu'ama practice their influence to procure government jobs for their political supporters. This excessive employment of individuals in the state, writes Chaaban, has increased the total base of public servants of which $16 \%$ constitute an additional Burdon on the state that amounts to an excessive annual expenditure of $\$ 396$ million (Chaaban 2011). These individuals vie for positions in state offices because of the pension plans and medical insurance associated with these positions. Using a mixed approach - economic regression, surveys, and semi-structured interviews, Chen and Cammett reveal that individuals that tend to show high levels of political activism with a political party in Lebanon receive greater access to finance in the field of healthcare (Chen and Cammett 2012). Therefore, Lebanese Zu'ama intercede on behalf of their supporters to secure jobs in the state and the benefits associated with those jobs, in return for the political loyalty of their supporters. This grim reality helps sustain confessionalism by virtue of strengthening the dependency of individuals on the Zu'ama.

To abolish this dependent Za'im-client relationship and thus debilitate the confessional mobilization of society, the liberation of the political space of social security becomes imperative to foster a non-confessional citizen-state relationship based on equal rights and duties for all. By suggesting the imposition of a mandatory social security program and old age pensions for all Lebanese citizens, this policy strategy, albeit partially reforming the system, precludes the possibility of political intervention in social security to serve personal political ends. More importantly, when Lebanese citizens receive their right to government-sponsored medical care without the intercession of influential Zu'ama, those individuals regain their trust and confidence in the Lebanese state regardless of their confessional affinity. In this scenario, the equitable provision of social security would be partially contributing to the emergence of a political space in which citizens can relate to the Lebanese state in a non-confessional manner and without feeling obligated to express political loyalty to the Lebanese Zu'ama.

\section{Administrative Decentralization}

Although the Lebanese political system is largely viewed as a democracy, albeit involving confessional quotas, the Lebanese Zu'ama enjoy a tremendous amount of political prerogatives due to their ability to mobilize their communities. As a consequence of this concentrated form of authority, these Zu'ama also determine who receive public contracts at the expense of transparency and political integrity. Recently in July 2015, the closure of one of Lebanon's largest landfills culminated in an ongoing garbage-collection crisis that brought tens of thousands to the streets to protest against government failure and at the outrageous price of approximately $\$ 150$ per ton of trash charged by the company that had monopolized the garbage industry in Lebanon. Though the government has succumbed to part of the demands fleshed out by protestors (El Husseini 2015), many remain dubious of 
government proposals and attempt to uncover the personal interests of the Lebanese Zu'ama behind this sanitary dossier.

This recent crisis in particular presents an interesting example of how administrative decentralization, which would inevitably translate to the ceding of some political authority from the Lebanese Za'im or politician to local municipal councils of towns and villages, can partially reform the Lebanese political order by providing the people the capacity to determine their local affairs, instead of relying on the political support of their Za'im. Though the Lebanese Zu'ama may seem adamant on preserving their political prerogatives in developmental matters to invest them for returns during electoral rounds etc, the mounting popular pressure in the streets of Beirut may actually succeed in placing the topic of administrative decentralization on the table for some serious discussion. Therefore, because of the instrumental ability of the Zu'ama to regenerate the confessional order to serve their interests, the Lebanese people may demand what they may, but must always be willing to settle for the best attainable solution. What determines the best attainable solution could be discerned by adopting a policy strategy that aims on achieving partial reform as opposed to abolishing the confessionally-imbued Lebanese political order at once.

\section{Contours of Policy Strategy}

I attempted to flesh out a policy strategy that reformists in Lebanon could adopt when dealing with any issue that coincides or collides with the prerogatives of the Lebanese Za'im in the confessional political order. This policy strategy is centered on aiming high but showing some flexibility by willing to accept solutions that provide them the ability to participate in public affairs more actively. In this sense, I considered that this strategy of partial reform liberates political spaces in which the citizen can participate with lesser reliance on the Za'im for political support. This is also why adopting a proportional representation, providing mandatory health care for all Lebanese citizens, and promoting administrative decentralization all promise to weaken the chains linking a community to its confessional leader or Za'im. This policy strategy may be modest in its aims, but is of great importance chiefly because it may guide policy makers and activists to realizing the importance of settling for a solution that promises more avenue for participation in the political system without the intercession of the Za'im. Quite often policy makers and activists alike set extremely ambitious policy goals and end up receiving very little from the Lebanese political class. Therefore, I argue, the aim is to adopt this policy strategy that centers on partial reform in order to widen the avenues for citizen participation in the political system without the intervention of the influential Lebanese Zu'ama. 


\section{Conclusion}

I showcased how Lebanese Zu'ama played an instrumental role in dominating the confessional communities they represented. Across time, Lebanese Zu'ama have worked to regenerate the pattern of Za'im-client relationships that bogs society down by forming watertight Za'im-client relations based on the distribution of political, economic, and social services, bargaining for power-sharing arrangements that favor their interests, fostering relations with foreign powers that play an influential role in Lebanon, and embrace ideological views to mobilize their constituencies. By strengthening their grip on these dimensions, Lebanese Zu'ama possess the ability to mobilize their supporters both during the electoral seasons or for rounds of street fighting or conflict, the 1958 and 1975 Lebanese civil wars being a case in point. To break this vicious regenerating pattern of societal domination, I suggested a policy strategy that concentrates on partial reform instead of radical solutions, targets society as opposed to the state, and one that makes concessions by the Lebanese Zu'ama more plausible. Although the examples of elections and the social security reform were advanced, this policy strategy can be applied to virtually any aspect of reform in Lebanon. The main reason behind the almost universal applicability of this policy strategy to multiple dimensions of the policy realm is because it considers the relationship between Lebanese citizens and the state as constituting a political space. The objective of the policy strategy I put forth is to forge a direct relationship between the Lebanese citizen and the state without having to rely on the intercession of the Lebanese Za'im as an intermediary to insure what should be a right granted equally to all citizens. But since the Lebanese Zu'ama have dominated the system quite forcefully, I argue the policy strategy all reformers ought to adopt is one that centers on partial reform that gradually debilitates the authority of the Za'im and creates more political spaces for citizen participation in the political system.

Nevertheless, the enclosed analysis fleshes out a think piece that proposes a new approach to tackle an ongoing quagmire. This policy strategy did not attempt to culminate in an authoritative solution to the calamities of the Lebanese confessional order. It attempted to showcase that radical reforms in Lebanon is close to impossible due to the ability of the confessional system to regenerate itself on more than one level. Therefore, it strongly argued for the adoption of partial reforms and the liberation of political spaces. It hoped to reveal that the liberation of political spaces, such as social security, may redefine citizen-state relations along non-confessional lines and filter out the role of the political elite, whose only unaltruistic aim is to maintain their power in the political order. This piece was an earnest attempt to point out the faults of the policy process in Lebanon. Since many scholars had written about policy proposals in Lebanon, this paper took on a different bend and argued that the fault lay in the way policy is strategized in Lebanon - I.E. the way policy objectives and goals are placed and thought of. The above analysis may be examined with a grain of salt, however, it hopes to invoke a stream of research 
into the manner policies should be considered and tabled for discussion in Lebanon rather than simply pointing out the flaws in the Lebanese political order.

\section{References}

Abul-Husn L (1998) The Lebanese Conflict: Looking Inward. Colorado: Lynne Rienner Publishers.

Arsenian Ekmekji A (2012) Confessionalism and Electoral Reform in Lebanon. Briefing Paper, Aspen Institute.

Beydoun A (2003) A Note on Confessionalism [part 4]. In T Hanf, N Salam (Eds) Lebanon in Limbo: Postwar Society and State in an Uncertain Regional Environment. Germany: Nomos, Baden-Baden.

Brotherhood Agreement (1991) Treaty of Brotherhood, Cooperation and Coordination between the Syrian Arab Republic and the Lebanese Republic. United Nations Treaty Series, May 22, 1675, 1-28932.

Cammett M (2014) Compassionate Communalism: Welfaire and Sectarianism in Lebanon. Ithaca: Cornell University Press.

Chaaban J (2011) The Costs of the Lebanese Sectarian System. Mimeo: American University of Beirut.

Chen B, Cammett M (2012) Informal Politics and Inequity of Access to Health Care in Lebanon. International Journal for Inequity in Health: 11-23.

Choueiri Y M (Ed) (2007) Breaking the Cycle: Civil Wars in Lebanon. London: Stacey International

Dabbagh S, Deeb G, El-Khazen F, Kisirwani M (1997) The Lebanese Constitution. Arab Law Quarterly 12(2):224-261.

El-Husseini R (2012) Pax Syriana Elite Politics in Postwar Lebanon. New York: Syracuse University Press.

El Husseini R (2015) Lebanon Cabinet Approves Plan to End Trash Crisis. Retrieved from http://yhoo.it/1ipdCmr [Accessed: 9 September 2015].

Hanf T, Salam N (Eds) (2003) Lebanon in Limbo: Postwar Society and State in an Uncertain Regional Environment. Germany: Nomos, Baden-Baden.

Hottinger A (1961) Zu'ama' and Parties in the Lebanese Crisis of 1958. Middle East Journal 15(2):127-140.

Johnson M (1986) Class and Client in Beirut: The Sunni Muslim Community and the Lebanese State 1840-1985. London: Ithaca Press: 48-49, 84.

Khalaf S (1968) Primordial Ties and Politics in Lebanon. Middle Eastern Studies 4(3):243-269.

Khalaf S (2004) On Roots and Routes: the Reassertion of Primordial Loyalties [part 6]. In T Hanf, N Salam (Eds) Lebanon in Limbo: Postwar Society and State in an Uncertain Regional Environment. Germany: Nomos, Baden-Baden.

Khalaf S, Denoeux G (1988) Urban Networks and Political Conflict in Lebanon [chapter 10]. In N Shehadi, M Haffar, D Mills (Eds) Lebanon: a History of Conflict and Consensus. London: I.B. Tauris.

Khalidi W (1989) Lebanon: Yesterday and Tomorrow. Middle East Journal 43(3): 375-387.

Kingston P W T (2013) Reproducing Sectarianism: Advocacy Networks and the Politics of Civil Society in Postwar Lebanon. New York: SUNY Press.

Orthodox Electoral Law (2013) Orthodox Law, Retrieved from http://bit.ly/1Nrf2rt [ 
Accessed 19 February 2015].

Pansters W G (2012) Zones of State Making: Violence, Coercion, and Hegemony in Twentieth-Century Mexico. In W G Pansters (Ed) Violence, Coercion, and StateMaking in Twentieth-Century Mexico: The Other Half of the Centaur. California: Stanford University Press: 3-39.

Picard E (1996) Lebanon: A Shattered Country. New York: Hol-mes\& Meier.

Salam N (Ed) (2004) Options for Lebanon. London: I.B.Tauris.

Salibi K S (1976) Crossroads to Civil War: Lebanon 1958-1976. New York: Caravan Books.

Solh R (1988) The Attitude of the Arab Nationalists towards Greater Lebanon during the 1930s [chapter 8]. In N Shehade, D Haffar Mills (Eds) Lebanon: a History of Conflict and Consensus. London: I.B. Tauriss.

Traboulsi F (2012) A History of Modern Lebanon. $2^{\text {nd }}$ edition, London: Pluto Press: $41-42,92$. 
